\title{
BAITUSSALAM KETINTANG SURABAYA JUNIOR HIGH SCHOOL REMAINS ON LINE LEARNING SERVICES IN PLAGUE OF VIRUS CORONA / COVID 19
}

\author{
Herlis Silviana \\ Junior High School of baitussalam Surabaya \\ Email : herlissilviana080@gmail.com
}

\begin{abstract}
Purpose: This viral infection is called COVID-19 and was first discovered in Wuhan city, China, in late December 2019. The virus is contagious rapidly and has spread to other regions of China and to several countries, including Indonesia. Corona virus is a collection of viruses that can infect the respiratory system. In many cases, the virus causes only mild respiratory infections, such as flu. However, the virus can also cause severe respiratory infections, such as lung infection (pneumonia), Middle-East Respiratory Syndrome In the midst of the relentless policy of Merdeka Belajar the policy is to study at home. It's been more than two weeks of schooling we've had off, but the learning process of teaching continues through activities at home. Teachers teach from their own homes, students study in their homes. Home learning can use self-learning models, online learning,ICT-assisted learning, or other forms..
\end{abstract}

Design/methodology/approach: Our research uses a type of qualitative research that explores data according to the facts that occur in the field with data collection methods through interviews, observations and documentation to obtain the results of research that occurs in schools and campuses during the coronavirus lokdown/ covid 19.

Findings: Online learning process Refers to the circular of the minister of education and culture which mentions one of which is the process of learning and working can be done online and work at home. The learning process at SMP Baitussalam Ketintang Surabaya is still being carried out with various efforts. Either done online video calls or through special tasks given.

Research limitations/implications: We propose that educational institutions should be able to uncover locdown during the covid-19 pandemic wisely. Find the right solution to solve these online learning problems with creativity and thoughtful solutions. In the future, SMP Baitussalam Ketintang Surabaya continues to do its best during the social distancing period to continue to serve the educational process and serve students in the best way.

Keyword: Learning, SMP Baitussalam, coronavirus/covid 19.

Received: August $14^{\text {th }}, 2020$

Revised: September $16^{\text {th }}, 2020$

Published: September $30^{\text {th }}, 2020$

\section{INTRODUCTION}

The virus infection is called COVID-19 and was first discovered in wuhan city, China, in late December 2019. The virus is contagious rapidly and has spread to other regions of China and to several countries, including Indonesia. Corona virus is a collection of viruses that can infect the respiratory system. In many cases, the virus causes only mild respiratory infections, such as flu. However, the virus can also cause severe respiratory infections, such as pneumonia, Middle-East Respiratory Syndrome (MERS), and Severe Acute Respiratory Syndrome (SARS). 
The Covid-19 virus has a tremendous impact on the world in all areas of education. Restrictions on interaction with social distancing process are carried out in an effort to suppress the process of transmission of the virus. An extension of the state of emergency for coronavirus outbreaks to May 29, 2020 has been established. Until now it is not certain until when the coronavirus outbreak / covid 19 will be last and what the cure of the disease due to coronavirus / covid 19 is. All new can suggest prefentif measures to prevent the spread of coronavirus or Covid 119. Some policies are taken by the government for example by doing lockdowns, prohibiting activities that invite many people to gather. Disbursing schools, closing road access, spraying disenfected, closing inbound lanes of residents from abroad, and restricting local transportation.

"The principle of education policy during the Covid-19 pandemic is that the health and safety of students, educators, education personnel, families, and the community is the top priority in establishing learning policies," the Minister of Education, Nadiem Makarim, said in an online press conference, June 15, as reported by the Ministry of Education's official website..

\section{LITERATURE REVIEW}

\section{Effectiveness}

According to Hidayat (1986) effectiveness is a measure that states how far the target (quantity, quality and time) has been reached. Where the greater the percentage of targets achieved, the higher the effectiveness. While (DH. \& Handoko., 1997) explains that effectiveness is the ability to choose the right goal or the right equipment for the achievement of the specified goal. Effectiveness of the level of ability to achieve goals precisely and well.

Steers (1985) explains that effectiveness is the range of a program's efforts as a system with certain resources and means to meet its goals and objectives without crippling those means and resources and without putting unreasonable pressure on its implementation. In learning, careful planning is required, the creation of learning tools, strategy selection, media, techniques, learning models, and evaluation of learning that are all mutually sustainable. The need to use effective and innovative learning models so that the learning can be more varied and run smoothly. The use of the learning model is also tailored to the material to be taught so that the suitability between the two and all components becomes appropriate.

One indicator of learning effectiveness is the achievement of a learning goal. The goal of learning is achieved to the maximum, so it can be said that learning achieves its effectiveness. In addition, student engagement actively demonstrates learning efficiency. The teaching learning process is said to be effective if the learning can achieve the expected goals and students can absorb the subject matter and practice it.

Learning methods and strategies are now shifting by leading to a paradigm shift in education. It affects the function of educators as facilitators, mediators and motivators in the learning process. Teachers have always been considered learning centers, but have now turned into students as learning itself. One of the causes is the rapid advancement of information technology requiring a paradigm change in the learning process implemented by all students.

\section{E- Learning/ Online}

According to Khvilon \& Patru (2002) E-learning as any teaching and learning that uses electronic circuits (LAN, WAN, or internet) to convey the content of learning, interaction, or guidance. Hartley (2001) hexplains that E-learning is a type of teaching learning that allows students to teach materials using internet media, intranets or other computer network media. Rosenberg (2001) emphasizes that E-learnings refer to the use of internet technology to deliver a series of solutions that can improve knowledge and skills.

E-learning has shortened learning time and made study costs more economical. E-learning facilitates interaction between students with materials or materials, students with teachers or instructors and fellow learners. Students can share information with each other and can access learning materials at any time and repeatedly, in such conditions that students can further strengthen their mastery of learning materials. Within E-learning, those taking on the role of teachers are computers and electronic guides designed by "contents writers", E-learning designers and computer programmers.

\section{HYPOTHESIS}

Learning in the covid-19 pandemic era has edifying the creativity of teachers and lecturers as educators and students and students in carrying out learning tasks from schools/ campuses. 


\section{METHODOLOGY}

Our research uses a type of qualitative research that explores data according to the facts that occur in the field with data collection methods through interviews, observations and documentation to obtain the results of research that occurs in schools and campuses during coronavirus lokdown/ covid 19

The descriptive data analysis process is carried out with three lines of activity namely (1) data reduction or datareduction simplification; (2) data exposure (display); (3) conclusion verifying. In this study, data validity checks were conducted that included credibility, dependability and affirmability.

\section{RESULTS AND DISCUSSIONS}

Corona is currently a warm conversation. In any hemisphere, the corona still dominates public space. In a short time, his name became a trending topic, talked about here and there, and reported massively in print and electronic media. Severe Acute Respiratory Syndrome Coronavirus 2 (SARS-COV-2) better known as coronavirus is a new type of coronavirus that causes infectious diseases to humans.

Covid-19 is an infectious disease caused by a newly discovered type of coronavirus. Although it attacks the elderly more, it can actually attack anyone, from babies, children, to adults. This corona virus can cause mild ganguan in the respiratory system, severe lung infections, to death.

Corona Virus Disease 2019 (COVID-19) was first discovered in Wuhan city, China in late December 2019. The virus is contagious very quickly and has spread to almost all countries, including Indonesia, in just a few months. So the WHO on March 11, 2020 designated this outbreak as a global pandemic.

This led some countries to set policies to impose lockdowns in order to prevent the spread of coronavirus. In Indonesia itself, a large-scale Social Restriction (PSBB) policy was put in place to suppress the spread of the virus. Because Indonesia is doing PSBB, all activities carried out outdoors must be stopped until this pandemic subsides.

Some local governments decided to implement policies to disburse students and began implementing learning methods with online or online systems. This government policy came into effect in several provinces in Indonesia on Monday, March 16, 2020, which was also followed by other provinces. But that does not apply to some schools in each area. These schools are not ready with online learning systems, which require learning media such as mobile phones, laptops, or computers.

The online learning system is a face-to-face learning system between teachers and students but is done online using an internet network. Teachers must ensure teaching and learning activities continue, even if students are at home. The solution, teachers are required to design learning media as innovation by utilizing online media.

This is in accordance with the Minister of Education and Culture of the Republic of Indonesia related to Circular Letter No. 4 of 2020 on the Implementation of Education Policy in the Emergency Period of The Spread of Corona Virus Disease (COVID-19).

The learning system is implemented through a personal computer (PC) device or laptop connected to an internet connection. Teachers can do learning together at the same time using groups on social media such as WhatsApp (WA), telegram, instagram, zoom app or other media as learning media. Thus, teachers can ensure students follow learning at the same time, albeit in different places.

All sectors are feeling the impact of corona. The world of education is one of them. Judging by the events surrounding what is happening, both students and parents of students who do not have mobile phones to support online learning activities feel confused, so the school is looking for a solution to anticipate this. Some students who do not have mobile phones do learning in groups, so they do learning activities together. Start learning through videocalls connected to the teacher, asked questions one by one, and then sync through VoiceNote available on WhatsApp. The materials are also provided in the form of videos that are less than 2 minutes long.

The problem is not only found in the learning media system but the availability of quotas that require a high cost for students and teachers to facilitate the needs of online learning. Quotas purchased for internet needs are soaring and many parents of students are not prepared to increase the budget in providing internet networks.

This is also a very important issue for students, what time they should study and how much data (quota) they have, while their parents are low income or from the lower middle class (underweight). Until finally this kind of thing is charged to the parents of students who want their child to keep up with online learning.

Online learning cannot be separated from the internet network. Internet connection is one of the obstacles faced by students whose residence is difficult to access the internet, especially those students who live in rural, remote and disadvantaged areas. Even if someone uses a mobile network sometimes the network 
is unstable, because the geographical location is still far from the reach of the mobile signal. This is also a problem that occurs a lot in students who follow online learning so that it is not optimal implementation.

Many on social media shared the experiences of parents of students while accompanying their children to study both positive and negative. As for example, there are parents who are often grumpy about getting their child unruly so they can't stand it and want their child to re-study at school.

This event gives awareness to parents that educating the child is not easy, it takes great knowledge and patience. So with this incident parents should be aware and know how to guide their children in learning. After getting this experience, parents are expected to learn how to educate their children at home.

Be aware that teacher and student unpreparedness for online learning is also a problem. The transfer of conventional learning systems to online systems is very abrupt, with no proper preparation. But all of this must still be implemented in order for the learning process to run smoothly and students actively follow even in the condition of the Covid-19 pandemic.

The stutter of online learning is evident before us, not one or two schools but in some areas of Indonesia. The very important components of the online learning process need to be improved and improved. First and foremost is a stable internet network, then a capable gadget or computer, an application with a user friendly platform, san online socialization that is efficient, effective, continuous, and integrative to all educational stekholders.

The solution to this problem is that the government should provide policies by opening free online application services in collaboration with internet providers and applications to help with this online learning process. The government should also prepare an online-based curriculum and learning syllabus. For schools it is necessary to conduct online engineering guidance (bimtek) online implementation process and socialize to parents and students through print media and social media about the procedures of implementing online learning, related to their roles and duties.

In the online learning process, it is important to add educational messages to parents and students, about the covid-19 pandemic outbreak. Thus we find the same learning with face-to-face but online-based. The effect is very good, the program is on target, and the learning achievements are achieved.

There is a lesson learned from the world of education in the midst of the Covid-19 pandemic, which is that face-to-face learning with teachers proves more effective than online. This was presented by Universitas Brawijaya (UB) education expert Aulia Luqman Aziz to coincide with National Education Day 2020. "Forever the profession of teachers will not be replaced by technology" said Luqman in his statement on ub's official page, Saturday (2/5/2020). According to him full learning online, lately there have been many complaints from students and parents.

Some teachers in the school claim that online learning is not as effective as conventional learning activities (face-to-face), as some materials must be explained directly and more fully. In addition, the material delivered online is not necessarily understandable to all students. Based on the experience of teaching online, the system is only effective at assigning assignments, and it is likely that the results of the work of these assignments are given when students will enter, so the possibilities will accumulate.

Observing the experiences of some of these teachers, then teachers must also be ready to use technology according to the development of the times. Teachers should be able to create learning models and strategies that match the character of students in their schools. The use of several applications in online learning is very helpful for teachers in this learning process. Teachers should get used to teaching by utilizing complex online media that must be packaged effectively, easily accessible, and understood by students.

Thus teachers are required to design and design light and effective online learning, by utilizing the right devices or online media and according to the materials taught. Although online learning will provide a wider opportunity to explore the materials to be taught, teachers should be able to select and limit the extent of the material coverage and applications that match the materials and learning methods used.

The simplest thing teachers can do is make use of WhatsApp Group. The WhatsApp app is suitable for novice online students, as it is very simple and accessible to students. As for online teachers who have more passion, can improve their abilities by using various online learning applications.

But again, choose an app that suits the needs of the teacher and the student himself. Not all online learning apps can just be used. But it should be considered according to the needs of teachers and students, conformity to materials, limitations of infrastrukur devices such as tissues. It is very ineffective if the teacher teaches by using the zoom metting application but the network or signal in the area of the student's residence is not good.

The success of teachers in doing online learning in covid-19 pandemic situations is the ability of teachers to innovate designing, and crafting materials, learning methods, and applications that correspond to materials and methods. Creativity is the key to a teacher's success in being able to motivate their students to stay passionate about learning online and not become a psychic burden. 
In addition, the success of online learning during the Covid-19 period depends on the discipline of all parties. Therefore, the school/madrassa here needs to create a scheme by putting together good management in regulating the online learning system. This is done by creating a systematic, structured and simple schedule to facilitate parents' communication with the school so that their children who study at home can be monitored effectively.

Thus, online learning as an effective solution in home learning in order to break the covid-19 spread link, physical distancing (keeping a safe distance) is also a consideration of the chosen learning. Good cooperation between teachers, students, parents of students and school/madrasah is the deciding factor to make online learning more effective.

\section{CONCLUSION}

From the results of this study, the following conclusions

a. Teachers continue to provide learning during the covid-19 pandemic even though they can be directly through face-to-face activities but through online learning.

b. Online learning is carried out by delivering materials and assignments to students.

c. The learning process at SMP Baitussalam Ketintang Surabaya to date is still carried out with various efforts. Whether done online video calls or through special tasks given

\section{REFERENCES}

DH., B. S., \& Handoko., T. H. (1997). Manajemen Pemasaran Modern. Yogyakarta: Liberty. Hartley, D. E. (2001). Selling E-Learning. amerika: American Society for Training \& Development. Hidayat. (1986). Kinerja Karyawan. Yogyakarta: Gajah Mada University Press.

Khvilon, E., \& Patru, M. (2002). Information and communication technologies in teacher education: a planning guide. Retrieved November 11, 2020, from UNESCO Digital Library website: https://unesdoc.unesco.org/ark:/48223/pf0000129533

Rosenberg, M. J. (2001). E-Learning Strategies for Delivering Knowledge in the Digital Age. ,New York. References - Scientific Research Publishing. Retrieved November 11, 2020, from McGraw-Hill website: https://www.scirp.org/(S(i43dyn45teexjx455qlt3d2q))/reference/ReferencesPapers.aspx?ReferenceID=1 165124

Steers, R. M. (1985). Efektivitas Organisasi Kaidah Peri Laku (Alih Bahasa Magdalena). Jakarta: Erlangga. 